\title{
Improvement of an induced autotetraploid population of Lotus tenuis for their use in the Flooding Pampas
}

\author{
M. Barufaldi ${ }^{1}$, Y, Villacampa ${ }^{2}$, F. García-Alonso ${ }^{2}$ \\ \& P. Sastre-Vázquez ${ }^{3}$ \\ ${ }^{1}$ Department of Agricultural and Biological Basic Sciences, CIISAS, \\ Faculty of Agriculture, Azul-UNCPBA, Argentina \\ ${ }^{3}$ Area of Mathematics, Faculty of Agriculture, Azul-UNCPBA, Argentina \\ ${ }^{2}$ Department of Applied Mathematics, University of Alicante, Spain
}

\begin{abstract}
In the Flooding Pampas, Argentina, as agricultural expansion spread into areas historically used for livestock grazing, it came to occupy the best soils in the area. The need therefore arose to increase the production of forage species able to adapt to increasingly stressed soil conditions.

Lotus tenuis is an exotic leguminous forage plant that has successfully acclimatised to the ecological conditions of the natural pastures in the Pampa Deprimida area. It is hugely important for the animal production systems operating in the region.

The plants of the induced autotetraploid population known as "Leonel" $(2 \mathrm{n}=4 \mathrm{x}=24)$ are larger, more vigorous and more productive than their diploid counterparts. They produce fewer yet heavier seeds.

The objective of this study is to assess certain aspects of seed production in autotetraploid plants selected by the following characteristics: plant vigour, production of dry matter and persistence.

A field trial was conducted over two years with 20 selected genotypes. A block design with three repetitions was used. The following variables were assessed: number of flowers and pods by inflorescence; plant vigour; total number of seeds, both in full and pod by pod; and weight per thousand seeds. Variables were transformed when necessary for the data analysis.
\end{abstract}


A complete model was considered, with the factors of genotypes and year. For the NF and NP variables, highly significant genotype-year interaction was detected, whereas for the rest of the variables no such effect was observed. In broad terms, the estimated values of hereditability suggest that genetic advances may be achieved for most of the variables studied. The results obtained allow superior genotypes to be selected in order to increase seed production in the enhancement programme.

Keywords: Lotus tenuis, induced autotetraploid, grassland, heritability in wide sense.

\section{Introduction}

The Pampa Deprimida, or Flooding Pampas, is a vast plain stretching to the northeast and southwest of Tandilia hills in the province of Buenos Aires (Fig. 1). It includes the areas known as the Salado River Depression, or Basin, and the Region of Laprida [1] (Figure 1).

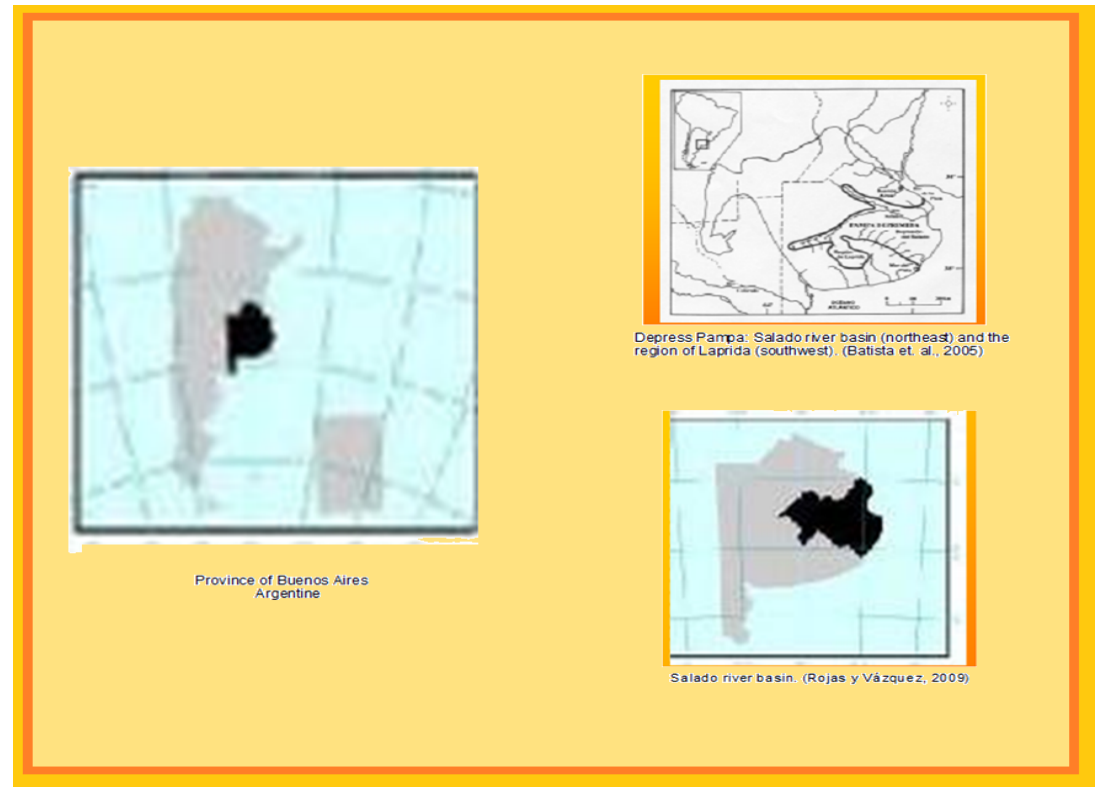

Figure 1: $\quad$ The Depressed Pampas or Flooding Pampas.

The largest area in this region is covered by the Basin of the Salado River, which includes much of the middle and lower basin of the Salado River, all the river systems of its tributaries and the Samborombón river system.

Surface and subsurface runoff of a 19 million hectares area is concentrated here [2] (Figure 1).

The climate of the region is template humid. The annual rain is $1100 \mathrm{~mm}$ in the northeast and $800 \mathrm{~mm}$ in the southwest. The intensity of rains is bigger during 
the spring-summery period. Theoretically, the global heating can increase the rains in the region, as well as its variability, accentuating the alternation of floods and droughts. The annual mean temperature is $13^{\circ} \mathrm{C}$ to $16^{\circ} \mathrm{C}$; with winter temperatures of $7^{\circ} \mathrm{C}$ to $9^{\circ} \mathrm{C}$ and summer ones of $20^{\circ} \mathrm{C}$ at $23^{\circ} \mathrm{C}$.

The region has very low gradients not exceeding 1 per mille, and many areas have gradients of around 0.5 per mille. This very limited slope of the land means that some areas are flooded (or flood-prone) by water excess for variable periods of time. The soils are predominantly hydrohalomorphic, being affected by waterlogging problems, sodium salts, alkalinity and poor drainage $[2,3]$.

The soils are generally suited to livestock farming, with some mixed areas for livestock and agricultural farming. The main activity is cattle breeding using an extensive system while natural grasslands are the main foraging resource $(85 \%)$. These grasslands are generally used throughout the year, with uncontrolled variations in the animal load that have a negative impact on many valuable species in plant communities $[4,5]$.

Another factor contributing to the degradation of these soils is the increasing expansion of agriculture in areas that are traditionally used for livestock farming. There is therefore a need to increase the production of forage species adapted to increasingly restrictive environmental conditions.

Lotus tenuis Waldst. et Kit (ex Lotus glaber Mill.) is an exotic forage perennial leguminous diploid $(2 \mathrm{n}=2 \mathrm{x}=12)$, which has been successfully adapted to the ecological conditions of the natural grassland of the Flooding Pampas. The productive cycle of this specie occurs during the spring-summerautumn period. [6]. Moreover, the frequent disturbances to the vegetation caused by farming, overgrazing, fire in tussock paspalum (Paspalum quadrifarium) communities and flooding have facilitated the colonization of these species [7].

Various factors have led this type of plant to be considered as a "key species" in the management of the region's grasslands: good adaptation to environmental conditions that restrict other leguminous plants; high nutritional quality of forage production and the lack of meteorism.

As part of a genetic improvement program, it was found an induced tetraploid population called Leonel $(2 n=4 x=24)$, which arises through colchicine treatment of seedlings obtained from naturalized seeds of $L$. tenuis populations.

Plants of induced autotetraploid population are larger and also more vigorous and productive than their diploid counterparts. Although less seeds are produced, they are heavier. The drawback of induced autotetraploid is the reduced seed production due to irregularities in their meioses, which lead to the formation of a significant proportion of unviable gametes, responsible for reduced fertility when compared with diploid forms [6].

However, studies carried out on autotetraploid Trifolium pratense [8] and researches on Secale cereale [9] have achieved increases in seed production of induced autotetraploid forms thanks to natural and artificial selection after the first multiple-crossing generations. The seeds production increase is an important character to be considered in the improvement plan of Lotus tetraploid for their multiplication. 
Genetic variability is an essential prerequisite in the selection process for any progress in an improvement plan. The genetics of a metric trait are based on the study of phenotypic variability and the partition of its components: genotypic variance (genetic differences between genotypes), environmental variance (of non-genetic origin), and genotype-environment interaction variance. The latter measures the differential behaviour of genotypes depending on the environment in which they develop.

The parameter of broad-sense heritability $\left(\mathrm{H}^{2}{ }_{\mathrm{W}}\right)$ indicates the proportion of total variance due to genetic effects. The heritability of a given trait can vary between 0 and 1 . High heritability values suggest that the variation is genetic, which enables progress by selection to be predicted.

The goal of the present work was to evaluate some characters related with the seed production in autotetraploids plants selected by their plant vigor, production of dry matter and persistence, in order to estimate statistical and genetic parameters.

\section{Materials and methods}

The experiment was developed in the Experimental Farm belonging to the Faculty of Agriculture, in the Department of Azul (latitude $36^{\circ} 45^{\prime} \mathrm{S}$, longitude $59^{\circ} 57^{\prime} \mathrm{W}, 137 \mathrm{~m}$ above mean sea level), in 2009 and 2010. These years presented very similar climate data for temperature and rainfall.

There were selected 20 genotypes (plants) from all the plants that had presented a superior performance in the following traits in the previous cycle: vigour, dry matter and persistence. Three clones of each plant were taken and transplanted to plastic pots with a proportional mix of sand, soil and peat to homogenize the soil factor. The plants were kept in an unheated greenhouse between May and July, and regularly watered to encourage vegetative growth.

The plants were transplanted in August at a distance of $0.60 \mathrm{~m}$ from each other. It was used a completely random block design with 3 repetitions according to the Turessonian Technique of Cultivation in a Standard Garden [10]. This technique highlights the effects of the environment on each individual plant, and enables an accurate estimation of the genetic expression of each trait. Supplementary irrigation was provided until the plant was completely established. Weed control was carried out manually around each plant.

The variables evaluated were: number of flowers (NF) and pods for inflorescence (NP); vigor of plants (VP); number of full (NFS) and empty seeds (NES) for pod and weight of a thousand seeds (WS). In the cases where it was required, some variables had to be transformed for the data analysis. It was considered a complete model with the "genotype" and "year" factors and the estimated values of heritability in wide sense were calculated $\left(\mathrm{H}^{2}\right)$.

A multivariate analysis of variance (MANOVA) was used to perform simultaneous inferences on all the variables studied over the two-year period. It was considered a complete model, in randomized blocks, with two factors, genotypes and year, and the interaction between them. 
In order to analyze the variability within each year, models in randomized blocks were considered for each variable with the factor "genotypes". A univariate analysis of variance (ANOVA) was used to make inferences between the means of all the variables studied. The means were compared with Tukey's test at $5 \%$. The model for $\mathbf{Y}_{\mathbf{i j}}$ and the parameters involved were:

$$
Y_{i j}=\mu+\alpha_{i}+\beta_{j}+\varepsilon_{i j}
$$

where $\mu$ is the overall mean, $\alpha_{i}$ is the variance component due to genotypes, $\beta_{j}$ is the variance component due to blocks and $\varepsilon_{\mathrm{ij}}$ is the variance component due to experimental error, which is assumed to be distributed normally and independently, with a mean of 0 and a variance of $\sigma_{\mathrm{e}}^{2}$. Table 1 shows the estimates for this model.

Table 1: $\quad$ Variance analysis for each year.

\begin{tabular}{|c|c|c|}
\hline Variation sources & $\mathrm{gl}$ & $\mathrm{E}(\mathrm{CM})$ \\
\hline Blocks & $\mathrm{r}-1$ & $\sigma_{\mathrm{e}}^{2}+\mathrm{r} \sigma_{\mathrm{g}}^{2}$ \\
\hline Between genotypes & $\mathrm{g}-1$ & $\sigma_{\mathrm{e}}^{2}$ \\
\hline $\begin{array}{c}\text { within genotypes } \\
\text { (residual) }\end{array}$ & $(\mathrm{g}-1)(\mathrm{r}-1)$ & \\
\hline Total & $\mathrm{gr}-1$ & \\
\hline
\end{tabular}

The following F-test was constructed to test the significance of the variance component attributed to the genotypes:

$$
\mathrm{F}_{\mathrm{GEN}}=\text { Mean Square of genotypes/Mean Square of the error }
$$

\subsection{Estimation of phenotypic variance and its components}

The genetic variance $\left(\sigma_{\mathrm{G}}^{2}\right)$ for each of the traits studied was calculated based on the analysis of variance performed for each year.

(i) The genetic variance was estimated as:

$$
\sigma_{\mathrm{G}}^{2}=(\mathrm{CMg}-\mathrm{CMe}) / \mathrm{r}
$$

where: $\mathrm{CMg}=$ Genotype mean square, $\mathrm{CMe}=$ Environmental mean square and $r=$ number of repetitions.

(ii) The environmental variance $\left(\sigma^{2}\right)$ was estimated as:

$$
\sigma_{\mathrm{E}}^{2}=\mathrm{CMe}
$$

This estimate does not have a genetic component, and consists of a microenvironmental variation.

(iii) The phenotypic variance $\left(\sigma_{\mathrm{P}}^{2}\right)$ was estimated as:

$$
\sigma_{\mathrm{P}=\sigma_{\mathrm{G}}^{2}}^{2}+\mathrm{CMe}
$$




\subsection{Estimated broad-sense heritability $\left(\mathrm{H}_{\mathrm{b}}{ }_{\mathrm{b}}\right)$}

With the estimated variance components obtained from the analysis of variance, we estimated the broad-sense heritability $\left(\mathrm{H}^{2}{ }_{\mathrm{a}}\right)$ based on the following expression:

$$
\mathrm{H}_{\text {broad }}^{2}=\sigma_{\mathrm{G} / \sigma_{\mathrm{P}}^{2}}^{2}
$$

We also calculated the coefficients for genetic variation $\left(\mathrm{CV}_{\mathrm{G}}\right)$ and phenotypic variation $\left(\mathrm{CV}_{\mathrm{F}}\right)$ by means of the ratios:

$$
\begin{aligned}
& \mathrm{CV}_{\mathrm{G}}=\left(\sigma_{\mathrm{G}}^{2}\right)^{1 / 2} / \text { Mean } \\
& \mathrm{CV}_{\mathrm{E}}=\left(\sigma_{\mathrm{E}}^{2}\right)^{1 / 2} / \text { Mean } \\
& \mathrm{CV}_{\mathrm{p}}=\left(\sigma_{\mathrm{P}}^{2}\right)^{1 / 2} / \text { Mean }
\end{aligned}
$$

which gives an index of the latent potential for advancement in a selected population.

\section{Results and discussion}

Multivariate analysis of variance (MANOVA) shows the existence of a genotype $\mathrm{x}$ year interaction for the statistically significant variables: number of flowers per inflorescence and number of pods per inflorescence.

Significant differences were observed for most of the traits evaluated in both years, except for the plant vigour variable. Table 2 presents the means, standard errors and mean squares for the traits evaluated in each year.

Table 2: $\quad$ Means, standard error and square means of the characters evaluated per year.

\begin{tabular}{cccc}
\hline Characters & Year & Mean & square means $\S$ \\
\hline Number of flowers & 2009 & $5.49 \pm 0.04$ & $15.898^{* * *}$ \\
per inflorescence & 2010 & $4.35 \pm 0.04$ & $12.025^{* * *}$ \\
\hline Number of pods & 2009 & $2.35 \pm 0.03$ & $17.317^{* * *}$ \\
per inflorescence & 2010 & $1.95 \pm 0.04$ & $6.581^{* * *}$ \\
\hline Number of total seeds & 2009 & $7.73 \pm 0.14$ & $25.345^{* * *}$ \\
per pod & 2010 & $7.54 \pm 0.14$ & $12.041^{*}$ \\
\hline Number of full seeds & 2009 & $6.435 \pm 0.12$ & $15.695^{* * *}$ \\
per pod & 2010 & $6.205 \pm 0.12$ & $6,357^{*}$ \\
\hline Number of empty seeds & 2009 & $1.30 \pm 0.07$ & $3.018^{*}$ \\
per pod & 2010 & $1.33 \pm 0.07$ & $3,348^{*}$ \\
\hline Weight of a thousand & 2009 & $1.73 \pm 0.01$ & $0.038^{* * *}$ \\
seeds & 2010 & $1.70 \pm 0.01$ & $0.032 * * *$ \\
\hline Plant vigor & 2009 & $4.45 \pm 0.15$ & $0.887 \mathrm{~ns}$ \\
& 2010 & $4.95 \pm 0.16$ & $0.897 \mathrm{~ns}$ \\
\hline
\end{tabular}

$\S * ; * * *$ significant differences at $\mathrm{P}<0.05$; and $\mathrm{P}<0.001$, respectively.

ns: differences non significant $\mathrm{P}<0.05$. 
According to [11], a very favourable situation for advancement by selection occurs when the relationship between $\mathrm{CV}_{\mathrm{G}}$ and $\mathrm{CV}_{\mathrm{E}}$ tends to one or exceeds this value. This is because the genetic variance is greater than the environmental variance. This shows that the traits with index values close to or greater than one have better conditions in terms of immediate genetic gain.

The characters number of flowers/inflorescence, number of pods /inflorescence and weight of a thousand, presented high values of heritability in a broad sense $\left(\mathrm{H}^{2}{ }_{\mathrm{W}}\right)$, in both years (Table 3$)$.

The ratios between genetic and environmental variation for these traits were greater than one for the two years. This enables the genetic advancement of these traits to be predicted by means of selection focused on increasing seed production.

Table 3: Genetic variance (VG), environmental variance (VE), phenotypic variance (VP), heritability in broad sense $\left(\mathrm{H}_{\mathrm{B}}^{2}\right)$, coefficients of genetic variation $\left(\mathrm{CV}_{\mathrm{G}}\right)$, phenotypic $\left(\mathrm{CV}_{\mathrm{P}}\right)$, environmental $\left(\mathrm{CV}_{\mathrm{E}}\right)$ and $\mathrm{CV}_{\mathrm{G} /} \mathrm{V}_{\mathrm{E}}$ for different traits in two years.

\begin{tabular}{|c|c|c|c|c|c|c|c|c|c|}
\hline Traits & Year & VG & VE & VP & $\mathbf{H}^{2} \mathbf{b}$ & $\mathrm{CV}_{\mathrm{G}} \%$ & $C V_{E} \%$ & $C V_{\mathrm{P}} \%$ & $\frac{C V_{G}}{V_{E}}$ \\
\hline \multirow{2}{*}{ NF } & 2009 & 4.82 & 1.44 & 6.26 & 0.77 & 39.98 & 21.86 & 45.57 & 1.83 \\
\hline & 2010 & 3.44 & 1.70 & 5.14 & 0.67 & 42.53 & 39.08 & 52.19 & 1.09 \\
\hline \multirow{2}{*}{ NP } & 2009 & 5.34 & 1.29 & 6.63 & 0.80 & 98.33 & 48 & 109 & 2.03 \\
\hline & 2010 & 1.81 & 1.14 & 2.95 & 0.61 & 68.99 & 28.08 & 88.08 & 2.45 \\
\hline \multirow{2}{*}{ VP } & 2009 & - & 0.96 & 0.96 & 0 & - & 22.02 & 22.02 & - \\
\hline & 2010 & - & 1.06 & 1.06 & 0 & - & 20.80 & 20.80 & - \\
\hline \multirow{2}{*}{ NS } & 2009 & 5.71 & 8.21 & 13.92 & 0.41 & 30.91 & 37.07 & 48.26 & 0.83 \\
\hline & 2010 & 1.32 & 8.07 & 9.39 & 0.14 & 15.24 & 37.68 & 40.64 & 0.40 \\
\hline \multirow{2}{*}{ NFS } & 2009 & 3.33 & & 9.04 & 0.37 & 28.36 & 37.13 & 46.72 & 0.76 \\
\hline & 2010 & 0.34 & 5.33 & 5.67 & 0.06 & 0.09 & 37.21 & 38.37 & 0.002 \\
\hline \multirow{2}{*}{ NES } & 2009 & 0.42 & 0.74 & 1.16 & 0.36 & 49 & 7 & 82 & 0.75 \\
\hline & 2010 & 0.54 & 1.72 & 2.26 & 0.24 & 55.25 & 98.61 & 113 & 0.56 \\
\hline \multirow{2}{*}{ WS } & 2009 & 0.12 & 0.01 & 0.13 & 0.92 & 20.02 & 5.78 & 20.84 & 3.46 \\
\hline & 2010 & 0.009 & 0.001 & 0.01 & 0.90 & 5.58 & 1.86 & 5.88 & 3.00 \\
\hline
\end{tabular}

NF: Number of flowers/inflorescence, NP: Number of pods/ inflorescence, VP: Plant vigor, NS: Number of total seeds/pod, NFS: Number of full seeds/pod, NES: Number of empty seeds/pod, WS: Weight of a thousand seeds. 
The analysed remaining variables have low values for the estimates of these genetic parameters. This suggests that most of the phenotypic variability is due to environmental effects (Table 3).

\section{Conclusions}

These results indicate the existence of significant genetic variability for the traits: number of flowers/inflorescence, number of pods/inflorescence and weight of a thousand. These traits are therefore important and should be taken into consideration in order to increase seed production in the autotetraploid population.

A larger number of genotypes should be evaluated in future researches, in order to ascertain genetic variation in the traits that presented low heritability.

\section{References}

[1] Batista, W.B.; M.A. Taboada; R.S. Lavado; S.B. Perelman and R.J.C. León. 2005. Asociación entre comunidades vegetales y suelos en el pastizal de la Pampa Deprimida. pp. 113-129 en: Oesterheld, M., M. Aguiar, C. Ghersa and J.M. Paruelo (eds.). La heterogeneidad de la vegetación de los agroecosistemas. Editorial Facultad de Agronomía. [pdf file].

[2] Vázquez, P.; Cabria, F.; Rojas, M. and Calandroni, M. 2009. Riesgo de anegamiento: Estimaciones para la Cuenca baja del río Salado. Revista de la Asociación Argentina de la Ciencia del Suelo 27 (2): 237-246.

[3] Lucero, L. G.; Mestelan, S.; Entraigas, I. y Migueltorena, 2012. V. Variabilidad de suelos de peladares de la cuenca baja del arroyo del Azul. XIX Congreso Latinoamericano y XXIII Congreso Nacional de la Ciencia del Suelo. Trabajo completo (6 pp) en CD-Rom.

[4] Ixtaina, V.Y.; Mújica, M.M. y Hang, G. 2005. Conservación de la variabilidad genética y uso sustentable de Lotus glaber Mill. en la Pampa Deprimida Bonaerense, Argentina: rol del productor agropecuario. AgroCiencia 20(1): 27-47.

[5] De La Vega, M. 2011. Pastizales Naturales: propuestas para su mejoramiento. Sitio Argentino de Producción Animal. pp. 1-4. http//www.inta.gob.ar/documentos/pastizales-naturales-propuestas-para-sumejoramiento.

[6] Barufaldi, M; Sastre-Vázquez, P; Villacampa, Y.; García-Alonso, F.; Reyes, J.A. and ALONSO, A. 2009. Lotus glaber Mill: Comparison of some morphological-physiological characters, between an induced autotetraploid population and diploid cultivars. Ecosystems and Sustainable Development, pp. 61-70.

[7] Barufaldi, M.; Valincenti, R. and Mestelan, S. 2012. Variabilidad fenotípica de una población naturalizada de Lotus tenuis Waldst. et Kit. en la Cuenca del Arroyo Azul, Pampa Deprimida. I Jornadas Nacionales de Ambiente. Área Temática: Gestión y Conservación de Recursos Naturales vegetación y flora. . Facultad de Ciencias Humanas, UNICEN. Tandil, Provincia de 
Buenos Aires, 1 de octubre al 2 de noviembre. pp. 86-95, ISBN 978-950658-315-6.

[8] Dennis, B. A. (1980). Mejoramiento genético de la producción de semilla de Trifolium pratense L. autotetraploide. In: Producción moderna de semillas. Ed. Hemisferio Sur. pp. 276-290.

[9] Pérez, J. (1980). La poliploidía inducida como método de mejora del centeno forrajero. Actas IV Congreso Latinoamericano de Genética. 2: 457463.

[10] Turesson, G. (1922). The genotypical response of the plant species to the habitat. Hereditas 3: 211-350.

[11] Vencosvsky, R.(1987). Herança Quantitativa. In: E. Paterniani (ed). Melhoramiento e Produçao do Miho no Brasil. Ediçao da Fundaçao Cargil. Instituto de Genética, Escuela Superior de Agricultura Luis de Queiroz, Universida de Sao Paulo. Piracicaba. Sao Paulo, Brasil. pp. 122-199. 